\title{
Mythologizing the Narrative: An Analytical Study of Turnage/Berkoff's Greek (1989) and the Nature of Operatic Narrative
}

\author{
Alexander Chih-Yuan Mai \\ Department of Foreign Studies, Kansai Gaidai University, Osaka, Japan \\ Email address: \\ acmai@kansaigaidai.ac.jp \\ To cite this article: \\ Alexander Chih-Yuan Mai. Mythologizing the Narrative: An Analytical Study of Turnage/Berkoff's Greek (1989) and the Nature of Operatic \\ Narrative. English Language, Literature \& Culture. Vol. 6, No. 3, 2021, pp. 82-90. doi: 10.11648/j.ellc.20210603.15
}

Received: June 27, 2021; Accepted: July 19, 2021; Published: July 29, 2021

\begin{abstract}
This paper focuses on literary adaptation of the genre of music theatre, i.e. opera and its strong association with mythic narrative. It will begin with a brief discussion on the hybrid nature of music theatre and its inner struggle between the Apollonian/verbal and the Dionysian/musical principles. In order to fully apprehend operatic narrative, it is necessary to explore the connection between opera and its predecessor, the ancient Greek theatre and the genre's association with myth and ritual. The paper will analyse a twentieth century English operatic adaptation and its social and cultural implications by using Greek (1989) as an example. In crafting a modern version of an ancient myth, some plausible equivalence of the original narrative motivation must be incorporated if the functional and explanatory elements are not to be lost. Opera can be considered to be the direct descendent of its ancient Greek predecessor. Furthermore, from a social and cultural prospective, opera has transformed the ancient rite of religious sacrifice into a secular social and communal offering. The nature of operatic libretto also reflects the essential characteristics of a double sacrifice in the genre of music theatre. Singers offer their talents in representing the scapegoat in a pseudo religious ritual in the modern society; librettists offer words for the ultimate amalgamation with music in the genre of music theatre. The paper concludes with the idea that the genre of music theatre is designed to epitomise a condensation of human emotions and as an offering which corresponding to the modern society's need for ritualistic sacrifice and spiritual purification.
\end{abstract}

Keywords: Opera Libretti, Cultural Studies, Mythic Narrative, Operatic Adaptation

\section{Introduction}

Opera is an artistic format which is constituted by the amalgamation of words and music. Just as all kind collaborations, there would be certain degree of rivalry between the two major artistic disciplines in the genre i.e., works and music. The main object of the paper is to undertake a literary approach to a twentieth-century libretti, Greek (1989). The analysis will pay considerable attention to the continuing employment of mythic devices and the frequent occurrence of the sacrificial themes in music theatre. These two themes are not only served as an important basis for the theatrical narrative but also constituted a profound part of the aesthetic value in this unique artistic genre.

The paper will firstly explore the element of mythic narrative and the Apollonian character in the genre of music theatre. One of the methods to unpack the mythic and Apollonian qualities in music theatre is to study operatic adaptations. By studying operatic adaptations which are based on celebrated literary works, the importance and indicative characteristics of the genre can therefore be revealed. Friedrich Nietzsche remarks, "So the Apollonian tears us away from the Dionysian universality and allows us to delight in individuals; it chains the arousal of our compassion to these individuals, and through them it satisfies the sense of beauty which craves great and sublime form; it leads a procession of images of life past us and stimulates us to grasp in thought the core of life contained in them" [1].

Although opera is designed to be a balanced hybrid between music and words, a successful collaboration still depends upon the effectiveness of its narrative in creating instant emotional intoxication, something which can most 
powerfully be achieved by musical language, the Dionysian part of the enterprise. Therefore, reading a libretto can only achieve a limited and rational appreciation of the genre; because in an operatic presentation, music will have supplemented or even replaced words in capturing the irrationality of human expression. Even so, the readers still cannot ignore librettists' contributions in creating an operatic work. To read a libretto is to rationally analyse and understand an operatic opus by employing the Apollonian principles, to seek the precise meaning of a piece without the influence from the emotional intoxication which is derived directly from the presence of music.

\section{Oedipus Rex and Greek (1989)}

In Mark-Anthony Turnage's two act opera Greek, an adaptation of Steven Berkoff's play of the same title, the composer invites readers to associate the piece with an ancient legacy. The work revisits the Oedipus myth and transposes it into the East End of London in Britain in the 1980s. The surreal confrontation between Eddy, the protagonist, and the two man-eating Sphinxes highlights the hero's destiny. After successfully solving the monsters' riddle prior to destroying them, the victorious hero finally realizes that the woman to whom he has been married for ten years is, in fact, his biological mother. There follows the gruesome mime scene in which the protagonist seems to tear out his eyes and subsequently appears to die. This leads to a mock funeral procession in which the playwright attempts to set the piece in a tragic fashion in the manner of his predecessor. [2] However, in simply transplanting the Greek myth into a twentieth-century background, Berkoff fails to recreate any vital analogue of the mythic structure and its related social functions. Furthermore, the narrative style in Greek is inconsequential, in the sense that the various parts do not actually connect. Greek is, in fact, fundamentally a reflection on the playwright's own experience and consequently has only a tangential connection with the mythic source.

This rather severe judgement clearly rests on a number of foundational concepts and presuppositions that will have to be examined in some detail. For now, it can be said that one important function of a mythic narrative is to explain the formation and efficacy of certain social features. The legitimacy of kingship, for example, is frequently constituted in terms of a sacralised role for the ruling family or class in which the authenticating principle is constructed in the terms of mythic narrative which presents itself as a quasiexplanation of the mystery of origin and election. As the ruler, a king should also act as the representative of his nation both with regard to his society and towards the gods and is consequently required to bear the symbolic burden of its social upheaval and crisis. It is in this context that in order to resolve its social problems, the monarch will have to perform and offer various types of sacrifice to placate the gods or forces of nature.

In Oedipus Rex by Sophocles, the protagonist's ultimate self-sacrifice is not due to the fact that he is a man who has committed a crime but because he is the king of Thebes who happens to have killed his father and married his mother. In these crimes against nature Oedipus has lost the right to rule the city state and his subjects have to suffer the consequences. In any attempt at constructing a modern version of such a myth, some plausible analogue of the original narrative motivation must be found if the functional or explanatory elements are not to be lost. Mythic narratives are not simple material objects that can be just moved about from one room to another. They are deeply embedded in a rich social context and if simply removed without compensating adjustments being made, they die.

This point needs to be widened: as we shall see, the myth of the founding of Thebes is also a central theme in Hans Werner Henze, W. H. Auden and Chester Kallman's The Bassarids (1966). This opera provides a different example of a modernist interpretation of the ancient mythic narrative. Unlike the narratively incoherent and thematically confused Greek, The Bassarids not only stylistically updates the ancient myth through the eyes of modern psychoneurosis but also retains its original's mythic origin via its symbolic and allegorical functions and their obvious connections to recent European history. In its moral and theological perspectives, it thus harks back to a Greek theatre which seems to have had its origins in staged religious choral events, and whose connection with religion and the Dionysian cult persisted for some considerable time.

As well as the plays themselves being quasi-religious events, the mythological stories that form so important a part of the canon also have some grounding in civic religion. Further, although neither the Greeks nor the Romans ever had sacred books in the sense that the Bible or the Vedic hymns are sacred, mythic narratives were accepted as authoritative in their own right and in consequence would have been seen as telling some kind of truth, even if that truth is uncertain or obscure.

One important reason for the early Church being against the theatre was its association with a rival set of theologies and the Church wanted to claim an exclusive access to theological truth and authority. The classical plays derive their authority partly from their retelling of traditional legends, but more especially from their ritual or cultic position. And because they did not derive their authority from fixed inspired texts, they were able to display considerable variety as circumstances required. But if the stories were to have continued life through the changes of history and society, they had either to undergo some change of function and corresponding relocation in ritual and performance terms or be violently allegorised. As a result, the narratives of mythic drama, beside their possible claims to truth-telling, were already, to a considerable extent, to be considered as pure fiction.

Consequently, it does not seem necessary to regard the ancient Greeks as believing in the literal truth of these narratives. Because, as with almost all myths, the actual ontological commitments in myths are vague, the details of the stories may even be absurd without their status being undermined. Perhaps they should be thought of mainly as 
being "as if" narratives. Take the myth of the discovery of fire: the results of this discovery are so momentous it is as if Prometheus brought it directly down from the gods. Myths thus function as if true descriptions of some aspect of reality, for example the creation of the world or the mysteries of death and rebirth; though given their fluidity and frequent opacity it may be difficult to pin down what the exact truths are.

At the very least, mythic narratives may be describable in terms of some kind of allegory, but care should be exercised that the process of such "other description" does not become arbitrarily or severely reductive. In general terms, myths do not seem to be so much quasi-scientific explanations as explorations concerning "us": not just with regard to society and the nature of social bonds but also about who we are, why we are and what we are. The rituals with which they are associated are enactments of identity, solidarity and reconciliation. These rituals further connect the myths to notions of the sacred and indeed the rituals may be regarded as dramatic enactments of what the myths obscurely express in words.

Although Greek is offered by Berkoff himself as an "allegory of London life", the narrative style of the play does not sufficiently define the problem it poses let alone solve it or try to provide any resolution or understanding. The play is based on Berkoff's personal experience, but without any precise structural relation of identity or representativeness being offered. Michael Evans points out, "it is fascinating that Berkoff turned to Greek myth, when he wanted to deliver a more powerful social and political commentary. It is equally fascinating that Turnage turned Berkoff's outcry against the climate that spawned Thatcherism into an opera just at the time when Thatcher's monetarist policies, and her infamous denial that there is any such thing as society, had made real on the British streets the riots and police brutality that Berkoff had predicted in his Greek." [3] However, the playwright's overly generalized and unfocused style exposes the play as being in desperate need of narrative and emotional precision: it is a long journey from Thebes to unpleasant pubs or football matches.

While the title and characters of Greek suggest links with a mythic past, the play also exhibits differences and discontinuities. The opera/play exposes thematic disorientations in its text which offers itself as an adaptation of Sophocles' original play, Oedipus Rex. Yet in Greek, the featuring of the plague lacks the cohesion needed to bind the plot. In Sophocles' text, the plague is the result of Theban moral degeneration, whereas, in Berkoff's play the ten years devastating epidemic in London does not seem to have any of the explanatory or symbolic quality. The plague is featured by the playwright without any further explanation or even glancing connection with the main plot. The inclusion of the mythical plague in Greek only increases readers' bewilderment as Berkoff immediately abandons any hints of justification for its presence in the play, only mentioning it casually towards the end of the work. As a result, this catastrophic pandemic has had no real part in the action and no intelligible bearing on the plot or its background.

The plague does not prevent Eddy from prospering in his new home and furthermore, nothing that happens subsequently has any association with it. According to Berkoff, the plague is an allegory of "the gross acts of violence being perpetrated the length and breath of Britain $[\ldots]$ bombs in pubs and massive displays of frustration at the weekly ritual called football." [4] It would seem that the plague for Berkoff is simply an expression of his detestation of life in cosmopolitan London and certainly not a consequence or expression of the ethical impurity of the city. The suspicion arises that the plague is there only because it was first in Sophocles, not because it has some organic function. But in Sophocles' original, the plague is directly linked to the fact that Oedipus has killed his father and married his mother. In Greek, on the other hand, the plague has already existed for some time, without any dramatic or explanatory subtext, prior to the main action of the play.

These contextual discontinuities and incoherencies in Greek can be found in several key moments in the text. For example, the attempt to present a scene of the police rioting comes across as at best very laboured. This riot scene does not possess any discernible structural purpose and there is no storyline flowing from it or connected to the scene. It is just there as an occasion for Eddy to go into a café. Similarly, the appearance of the sphinx in Greek also gives rise to concerns. As the plot operates, the sudden emergence of the sphinx in the play strongly suggests that its deployment is mainly for the sake of forcing in an element of the original, not because the narrative requires such figure.

Furthermore, the sphinx in Berkoff's work is used to symbolise some kind of feminist ideology, but the point of this irritable and clichéd portrayal is far from clear. The audience is left wondering what the creature has to do with the actual plot of the piece. Sophocles' original takes the form of a mystery which must be solved for the stability and safety of Thebes. In Oedipus Rex, each step in the play is a further piece of the puzzle in which everything fits together with horrible logic and which will eventually lead to its tragic climax. However, in Greek the storyline merely drifts along with only the faintest memory of the Oedipus myth to give it shape. The main governing principle is that it should have something to do with the author himself. Even within whatever little shape the narrative has, there is little internal coherence in the plot, as the playwright does not attempt to connect the details of the story to one another.

Greek at least has the value of highlighting the concept of ritualistic offering which has always acted as an essential binding force of the great civilizations of the past - such as, the ancient Egyptian, the ancient Chinese and the Aztecan. [5] According to Adolf E. Jensen, "the killing [...] is an unavoidable concomitant of the respective acts, while the true motives of the ceremonies may be sought in other contexts. In many instances there can be no doubt that the killing is essential, that it constitutes an important, even decisive, part of the event." [6] However, instead of remodelling the Oedipus myth to express a fresh 
understanding of the ills of British society in the 1980's, Berkoff roughly transposes the ancient story into a modern setting as an eruption of personal snobbishness and discontent. By tearing the Oedipus myth from its vital context, Berkoff fails to make sense either of the ancient myth or of the condition of the twentieth-century audience. The symbolism in items such as the plague and the sphinx are vaguely conceived and show no sign of having been carefully thought through. In Sophocles' account, the tragedy is explicitly tied up with the political aspect of the plot, the position and moral health of the state being strongly dependant on that of the king. However, as Berkoff himself remarks, Greek needed no extra research because it is basically only about himself. [7] As a consequence, almost every aspect of Greek is absorbed into the wrapped contemplation of Eddy/Berkoff, which results in a prolonged narcissistic self-reflection, and certainly not the intricate moral or political analysis found in Oedipus Rex.

\section{Mythic Narrative}

Even with its manifold narrative inabilities, Greek still provides an example in terms of the function of a mythic narrative and the problems and difficulties which may arise when it is adapted into a different social and historical context. But using solely literary models such as the works of Sophocles in order to identify myth does not provide sufficient material to distinguish it at the narrative level; furthermore, it is doubtful that a purely formal definition of the term can be provided. Although it is unlikely that we can pinpoint a satisfactory description of myth even in a literary context, there are still a few features that can be offered as general indicators.

Firstly, myth tends to operate with a degree of remoteness which might be either (or both) chronological or geographical. Mythic narrative tends not to occur in the immediate present although distance may be achieved by other means such as being set in strongly different societies, shipwreck or freakish isolation. Secondly, mythic narrative has a tendency towards the elemental, when the issues being raised are of a powerfully basic sort, perhaps involving a stripping away of the fripperies of civilization, for example. Certain opacity of cause and effect is also a common element in mythic narrative. Take the plague in Oedipus Rex for instance.

The dramatic purpose of the epidemic at one level seems to be inviting allegorization, while at the same time suggesting that unknown forces or mechanisms, which may often involve inscrutable divine retribution, are at work. Myth is usually narrated in terms of past events being framed in such a way as to raise important and wide-ranging questions such as divine justice in the here and now. Unsurprisingly, there is a strong tendency towards elevated language and highly stylized situations. And finally, myth is frequently concerned with social, religious or political order.

Mythic narrative can also be categorized into four different archetypes. Firstly, the narrative depicts origins; for example, the source of a lineage, city or society and this often entails an account of the genesis of certain accompanying social features and structures. This type of myth will also include theologies. The second mythic archetype is a lineage/legitimacy narrative, which tells, for example, the story of how such and such a person came to be King and his pursuit and maintenance of power. The third archetype of mythic narrative is concerned with grave crises in public life in which the structure of society is threatened. The fourth and last type of myth is most often about insoluble conflicts in moral duties, especially among the ruling elites. Many of these narratives will concern themselves with gods or other supernatural entities and because of their narrative implications, it is not difficult to understand that a frequent theme in a mythic story is that of sacrifice.

The sacrificial theme in mythic narrative will frequently involve the king or hero as representative of his people. In order to restore the status quo, he has to sacrifice himself or a member of his family. Secondly, during a period of social crisis, a scapegoat may be found to carry and purge the burden of public guilt. One subtype of this would be the "everyman" as the symbolic sacrifice. The third sacrificial theme in myth is encapsulated in the biblical story of Moses. As the liberator of the Israelites, the prophet can, mysteriously, never enter the Promised Land. His function as liberator exhausts his role and the sacrifice seems a necessary element of his finished achievement. Finally, sacrifice is used as topos or theme in a quasi-mythic narrative.

As the modern world gradually turns into a more democratic society, people no longer have the king as effective surrogate for the community. The public's search for a social scapegoat has switched to the eminent members of the society, or even to "celebrities". The dramatization of the life of the excessively daring Margaret Argyll represents a modern reflex of this type of mythic narrative. Powder Her Face (1995) is dealing with the notion of "tabloid myth" which is an attempt by the newspapers to construct a mythical narrative out of almost real events. The infamous duchess was only famous for her divorce from her second husband, the Duke of Argyll. The notoriously lengthy legal battle caught the public's imagination and allowed them a vicarious insight into the life of the upper class and with the concomitant effect of them being eager to see her humiliated and destroyed. Despite the strong presence of "moralizing", this form has no sacred or even moral bearing.

This discussion, besides providing some general framework, allows us to return to Greek in the hope of further clarifying our problems. Even though Greek is clearly derived from the myth of Oedipus, this twentieth-century adaptation of Sophocles' original cannot be categorised as a form of mythical narrative. In Oedipus Rex, the king is the embodiment of the state and as such he is the source as well as the symbol of the health or weakness of the nation. The origin of the plague in Oedipus Rex is associated with the life and action of the king. On the other hand, in Greek, Eddy is merely the co-owner of a café which is not presented as having any symbolic or representational value in the play.

The playwright has suggested that the protagonist in Greek 
is a representation of "everyman". But the purpose of featuring an "everyman" in a play is that in his ordinariness he can be used as a symbolic figure to represent the entire community. In this he must be typical. However, killing a sphinx is work for heroes, while marrying one's mother are neither typical nor the accepted social norm and it is hard to see how in either case they can be taken to be representative of society. Although Eddy has indeed committed incest, being merely a café co-owner, there is no reason to suppose that this moral deficit is applied to a figure with any general symbolic or functional position. Even as a scapegoat it would be hard to see what burden he might bear for the population at large.

One element of the role of the ordinary individual can be that they become representative of the society around them and this representative status may often involve their sacrifice, even though the function of sacrifice in modernist thinking is considerably different from that of Greek tragedy. The final mock funeral procession gives the game away entirely. Eddy not only comes back to full, unblinded life, he cheerfully decides to continue his relationship with his mother. In other words, the whole moral-mythic content of the play is simply discarded, the symbolic framework nullified and Sophocles jeered at - leaving us with nothing but roaring egotism.

The impression is given that the final section has been hastily attached to the main story for shock value, not for the purpose of enhancing or developing the plot - though it unwittingly reveals the play's true intention. In order to create a balanced adaptation, it is crucial for the librettist to work out the actual dramatic function of the myth and its meaning before devising some analogue of the original to be re-interpreted in a completely different context. Structurally, because Greek does not feature a chorus, the opera instantly lacks the sense of formality which might have connected it with its mythic roots

The chorus, the signature narrative device in ancient Greek theatre, not only provides commentary on the actions through the formats of singing and dancing but also presents the ritualistic essence of this mythic genre. Unfortunately, Berkoff does not find a satisfactory analogue into which he might successfully transpose these vital contextual elements from Oedipus Rex into Greek, so he simply unloads into his adaptation the scattered bones of the story together with a few symbols which in consequence do not possess anything of the same effect or purpose.

\section{Ritualistic Sacrifice}

Music theatre is the only medium in which the "Dionysiac" and "Apollonian" principles routinely collide. These contrasting principles are often seen as constituting two essential poles of attraction for human nature. However, aesthetic confrontation between instinctual, pre-rational musical expression has to find a balance with the rational, ordered verbal representation. As Nietzsche notes, "the tragic myth is to be understood only as a transformation of the wisdom of Dionysus into images through the artistic means of Apollo; the myth pushes the world of phenomena up against its limits where it negates itself and seeks to flee back into the womb of the one true reality." [8].

Music can penetrate further into people's minds in the understanding of a dramatic situation. For example, in The Bassarids (1968), the use of harp in the confrontation between Pentheus and Dionysus atmospherically enhances the presence of Dionysus. Henze's music therefore, adds a further expressive dimension to Auden and Kallman's words. The combination of "music" and "tragic myth" in a theatrical presentation exceeds the spectators' expectations in achieving their ultimate physical and spiritual heights. Nietzsche's argument intends to normalize Greek theatre in terms of "aspects of human nature", which everyone shares.

These arguments present myth as being interiorized in the manner of Richard Wagner's theory of music drama. Sigmund Freud later absorbs the tenor of Wagner's arguments and psychologizes them, associating such interiorized human conduct with the individual's problematic psychic history. The late nineteenth-century science of anthropology, on the other hand, takes a different route in interpreting Greek myth. It borrows from another new science, sociology, notions of social function and utility and attempts to explain myth and ritual in terms of social bonding and coded hierarchies, such as we see at work in Igor Stravinsky's The Rite of Spring for example. According to this anthropological interpretation, ancient myth is the prime material to be examined and understood in the effort to understand its originating society but, unlike the psychological approach, it is not to be participated in.

Whichever style of reading we adopt, sacrifice should be considered one of the important elements in an operatic presentation and its appearance can be further categorized into two themes; performers can be interpreted as the reembodiment of the sacrificial victims such as those to be found in the ancient Greek era, while the verbal clarity in libretti must ultimately submit to the emotional expressiveness found in the musical language. [9].

Since the Renaissance period, the development of European music theatre has strongly mirrored important aspects of the history of Western civilization. [10] Furthermore, the golden age of the genre of western music theatre actually corresponds with the urbanization and modernization of the major European cities. [11] As modern Western society moved towards secularism after the renaissance period, people's fundamental need to investigate their spirituality had also found an outlet away from organized religion into a passion for music theatre. [12].

For the aristocrats of that period, music theatre was a symbol which also re-enforced their role as the ruling class. To quote Peter Conrad's observation, "throughout the nineteenth century, opera is an alternative religion, and its characters profess to be recondite pagan gods, or else their priests and priestesses." [13] Music theatre, therefore, functions as the re-embodiment of the ancient sacrificial altar for the rapidly changing modern Western society. [14] The 
passage provides an indication that the genre of music theatre can always change with time in order to adapt to its contemporary society.

From the sociological point of view, the reason for primitive people's notion that it was necessary to perform sacrificial rituals was twofold: firstly, to act as an instrument of social bonding and second, to offer gifts to the supernatural beings that they deemed it necessary to propitiate. [15] The word "sacrifice" etymologically derives from the Latin word sacrificium which signifies the action of facere, "to make" and sacer, "holy" in a religious context. A sacrificial rite would be a tripartite relation between the participants, the victims, and the god or deities with whom the participants intend to communicate.

The whole concept of sacrifice can be interpreted as part of the human behaviour of ritual exchange: by renouncing the valuable object, the entire community would receive far more precious returns. [16] Both prayer and sacrifice feature as essential elements in human cultures. While prayer may be personal, intimate and verbal, sacrifice is communal, presentational and extra-verbal. Sacrifice is the act of giftoffering in which by submitting treasured objects the worshippers are hoping to receive a god's favour in return.

Classical Greek drama provides one of the primitive examples of literary transformation in the function of sacrificial rites from the original purpose of ritualistic prayer into grand festive spectacle. [17] Although classical Athenian dramas remained attached to the religious context, in which the plays were performed in order to honour Dionysus during his religious festival, these theatrical works had a greater social purpose: to educate, to bind and to define the entire city state. [18] Ancient Greek theatre is the first step in the development of music theatre, enabling it to move on from its purely religious beginnings into an aesthetic and literal representation.

The change of musical expression in the twentieth-century is a manifestation of new aesthetic needs which found their form in the introduction of modernism. Writers and composers in the twentieth-century were looking for a satisfactory narrative form where nineteenth-century bourgeois conventions were felt no longer to suffice either at an individual or social level. This narrative uncertainty in the twentieth-century is exposed, firstly through the composers/writers' disruptive uses of myth and secondly, for example in expressionism, in their deliberate effort to blur the reality/myth distinction and by sometimes blending into a Romantic mode for referential assurance. In this lack of confidence, the first exit point for composers/writers was the quest for authenticity in verismo or literary ultra-realism, James Joyce's Ulysses for example. This finds a kind of extreme point in Alban Berg's Wozzeck (1925) where the old-fashioned domestic drama is taken to such a point of total disintegration that there can be no redemptive tragedy in the work.

A second remedy is symbolisme, as in Debussy's Pelléas et Mélisande (1902) and Bartók's Bluebeard's Castle (1918) for example. With symbolisme comes an interest in myth but not Wagnerian myth. The epochal symptoms such as the fragmentation of society or the individual personality, uncertainty about values associated with religion or conventional moral systems have a direct impact on musical manner. The assumption behind the lyrical effusion which was manifested in the later eighteenth and nineteenth-century operatic aria is that here the audience has truth and sincerity, a unique access to the inner character. This notion of sincerity is not easily available to the twentieth-century writers and composers as the audience tends to see such outbursts as "stagey" and, post-Freud, at least unconsciously insincere. That is, the viewing spectators see them ironically. Irony becomes a persistent mode in modernist writing; to many, perhaps to a majority, irony seems an appropriate response to alienation.

As myth was being secularised, something analogous was happening to ritual. Civic ritual always existed alongside the religious, even though there is a persistent tendency for one realm to try to invade the other: at its coarsest generalisation, kings like to claim divine right, or priests try to supplant kings. Ancient stories need to be secularised as much as possible because explicit theology is fenced off by the Church; on the other hand, these ancient stories can be appropriated to the need for extra Court or civic ritual. In the sphere of Court art, this gives an impulse to the creation of an independent aesthetic, geared to the social and dynastic concerns that may be thought to stand to one side of the official theological and cultic requirements. This is most obvious with regard to theatre and opera. Medieval drama acted as an extension of the liturgy and Biblical narrative; with the Renaissance, drama and opera also becomes secularized. It is notable however that both of these, especially opera, remain highly ritualized art-forms, though in this case in a civic context.

From the time of its origin in the aristocratic courts of Italy, music theatre has been a conspicuously political art. [19] One of the earliest recorded operatic performances, Dafne in 1598, was to celebrate a civil union between two most powerful families. Music theatre was not only designed to mark the occasion but also intended to exhibit political supremacy. Such political implication still survives in twentieth-century works. Nixon in China (1988) depicts the clash of two political super powers and their leaders' intention to display their political influence through various "friendly" gestures. In this way, music theatre is able to reflect, in intricate and mediated formats, the significant political personages and events which have shaped the modern Western world, such as kings and coups, classes and class-conflict, rebels and revolutions. [20] Music theatre has also addressed many of the characteristic themes which constitute modern and contemporary political thoughts: monarchy and republicanism; the relationship between class, status, and gender; revolution and utopia; and the role of art and the artist within an increasingly complex society. [21].

Ritual and myth play a complex role in secular society: Court, coronation, the processes of election and government are all heavily ritualised and myths of various sorts are allpervasive, even if not always consciously so. While official theologies are yielded to the Church, the protean nature of 
myth allows a fluid slipping in and out of focus with regard to dogma while State ritual plays hide-and-seek with its liturgical analogues. Both myth and ritual are constantly remoulded to allow for the exploration of human concerns and it sometimes seems that virtually any old myth can be pressed into service.

The pervasiveness of myth does not indicate that there is no real or rational basis to public life; but it does mean that myth and reality overlap and one seems to need the other, even though the overlap is not complete or always comfortable. It can sometimes seem that the distinctions are being confused: politics can become a mythopoeic ritual in which the lines of reality are systematically blurred. For example, it is obvious to us that Louis XIV was not really a sun-god but everyone at the French court during that period was behaving as if he was and there was an enormous iconographic push to make it seem a reasonable connection. People will perform rituals as if they are reality and vice versa - what often counts is the assimilation of action or person to a mythic situation.

These imitative aspects of performing ritualistic spectacles in fact derive from the desire for religious sacrifices in human society. The central characters in music theatre represent a modern form of sacrificial victims in order to fulfil the audience's desire for achieving the ultimate jouissance. [22] The death of the protagonist in an operatic performance exhibits modern society's need for human sacrifice.

The demand for the representational sacrifice on the operatic stage echoes Hubert and Mauss' anthropologic study on the subject of sacrifice: "in sacrifice whose purpose is to fertilize the earth, that is, to infuse into it a divine life, or to render more active the life it may possess, there is no longer question, as before, of eliminating from it a sacred character. One must be communicated to it. Thus, the processes of direct or indirect communication are necessarily involved in operation of this kind. A spirit that will make it fertile must be fixed in the soil." [23] In music theatre, performers are able to act as the medium which communicates between the paying audience and its ecstatic fantasy. By leading their spectators into the ultimate jouissance, performers have therefore fertilized the audience's spirit through their symbolic and ritualistic sacrifice.

However, according to W. H. Auden, the primary world of human sacrifice has lost its place in a sophisticated modern society; and the symbolic form of human sacrifice which exists in the secondary world, therefore supersedes its savage predecessor. [24] There are many "typical" themes of mythic narrative; besides those already mentioned, there are others, perhaps less amenable to operatic treatment, such as cattleraids, shape-changing, vast journeys; all these themes are associated with the role of the hero and the situation of sacrifice.

Music theatre answers modern society's need for the symbolic form of human sacrifice. The genre captures the characteristics of a primitive ritual in a cultivated and representative manner. The protagonists in such a genre ultimately have to submit their lives to their fateful destiny; as if being a selected victim, the performers offer their talents to their audience and receive a rewarding artistic recognition and financial return. [25] Furthermore, the art form can also encompass four different types of dramatic but symbolic death in a theatrical format, namely, "the sacrificial victim", "the epic hero", "the tragic hero" and "the martyr", which serve as regenerators for society. [26] With its highly emotionally condensed dramatic characteristic, the genre of music theatre re-captures the human's primitive compulsion for blood sacrifice in a fully public and modern display. [27].

The role of a hero has been hinted at in the above with regard to Romance. Typically, the knightly hero has a representative function and many of his situations and actions are ritualised - this is a long way from realist fiction. Ritualization is necessary because of the hero's representative function: it has to be shown that he acts for and on behalf of his society and thus gathers to himself all the necessary symbols that allow this role to function. As it happens, the knight is more representative of his class than of society as a whole and this sectional interest are probably connected with the conspicuous scarcity of tragic sacrifice in romance narrative.

An operatic opus has always been perceived as being primarily a musical creation and the contribution from its librettist has tended to be neglected by the audience. Moreover, the libretto is not deemed to be a literary genre in its own right because of its conjunctive characteristic with its marital partner, namely, music. [28] As a renowned librettist, Auden reflects the difficulties to be found in attempting to master this unique art form: "a librettist is always at a disadvantage because operas are reviewed, not by literary or dramatic critics, but by music critics whose taste and understanding of poetry may be very limited. What is worse, a music critic who wishes to attack the music but is afraid to do so directly can always attack it indirectly by condemning the libretto." [29].

Thus, the libretto is a literary orphan, which has failed to attain its legitimate artistic status as a literary genre in its own right. While a spoken play is centred on characters and a plot, an opera libretto, on the other hand, will admit and even require many elements, such as dances, choruses, instrumental or vocal ensembles, and spectacular stage effects, which contribute little or nothing to characterization or to development of the action. [30].

\section{Conclusion}

Music theatre, being the artistic hybrid of music, literature and spectacle, is designed to represent a condensation of human emotions, as the offering corresponding to society's need for ritualistic sacrifice and spiritual purification. [31] However, due to the genre's hybrid characteristic, the two main components of music theatre, namely music and words are continually challenging poets and composers to find a harmonious artistic union. In the early seventeenth-century the artistic battle between literary expression and visual effect took place in the English court, where Ben Jonson's 
verse rivaled Inigo Jones' stage design in their collaboration on court masques. However, Jonson's wish for literary coherence and poetic beauty was discordant with Jones' concern for visual spectacle. The poet finally admitted defeat and withdrew from any further collaboration after 1631. [32].

It would seem that in the example of the artistic struggle between Jonson and Jones, the genre of music theatre encapsulates something of the contemporary concept of aesthetic values and their intersection with political trends. Furthermore, as an adaptation of pre-text literary works, the libretto can also pose questions of intertextuality, transposition of genre, and reception of history. As verbal artifacts, the genre draws upon the broad spectrum of contemporary reading strategies ranging from the formalistic to the feminist. And finally, as text for musical realization, the libretto raises issues in the relationship between the two media and their respective traditions. According to such perspectives, libretti are not 'beneath contempt as literature', but very much within the purview of contemporary humanistic scholarship. [33].

Although sacrifice has its origins in the rituals of propitiation and thanksgiving, its relation to myth entails that it will drift with myth into a more secular and aesthetic role, though it will still concern itself with social cohesion, definition and reconciliation. This said, modernist representations are less inclined to allow their central figures un-ironic heroism, the suggestion being, that to be representative is not to be heroic in the older sense and that the strong roles of the past need to be tempered either with a knowing irony or placed in such a conflicting situation that what was formerly opaque has become dark and perplexing. Instead of featuring Lancelot from the legends of King Arthur, the playwright will use Wozzeck (1925). This is signalling a change in the function and apprehension of sacrifice, but is not its negation: the locus of sacrificial value has simply shifted to reflect a view of society which still seeks cohesion and identity but is uncertain as to how these may be achieved or represented. It may be by the isolation and punishment of the eccentric individual or the crushing of innocent in the quest for reconciliation and harmony, but the sacrifice remains a vital component.

\section{References}

[1] F. Nietzsche, The Birth of Tragedy, trans. by Douglas Smith, Oxford: Oxford University Press, 2008, pp. 114.

[2] S. Pittitt, "Mark-Anthony Turnage 'Greek", Musical Times, cxxix, pp. 397, 1988.

[3] M. Evans, Opera from the Greek: Studies in the Poetics of Appropriation, New York: Routledge, 2016, pp. 184.

[4] S. Berkoff, Free Association: an autobiography, London: Faber, 1996, pp. 4.

[5] W. Burkert, Homo Necans: The Anthropology of Ancient Greek Sacrificial Ritual and Myth, trans. by P. Being, Berkeley: University of California Press, 1983, pp. 1-3.
[6] A. E. Jensen, Myth and Cult among Primitive People, trans. by M. T. Choldin and W. Weissleder, Chicago: University of Chicago Press, 1963, pp. 162.

[7] Berkoff, op. cit, pp. 4.

[8] F. Nietzsche, The Birth of Tragedy, trans. by Douglas Smith, Oxford: Oxford University Press, 2008, pp. 118.

[9] C. Abbate, In Search of Opera, Oxford: Princeton University Press, 2001, pp. 189-194.

[10] A. Gerhard, The Urbanization of Opera: Music Theatre in Paris in the Nineteenth century, trans. by M. Whittal, London: The University of Chicago Press, pp. 17-21.

[11] D. J. Grout and H. W. Williams, A Short History of Opera, New York: Columbia University Press, 2003, pp. 43-47.

[12] C. G. Jung, Jung: Selected Writings, ed. by A. Storr, London: Fontana Press, 1986, pp. 345-346.

[13] P. Conrad, A Song of Love and Death: the Meaning of Opera, London: The Hogarth Press, 1987, pp. 71.

[14] C. Lévi-Strauss, Structural Anthropology, trans. by M. Layton, vol. 2, Middlesex: Penguin Books, 1977, pp. 29-30.

[15] H. Hubert and M. Mauss, Sacrifice: Its Nature and Functions, trans. by W. D. Hall, Chicago: The University of Chicago Press, 1981, pp. 2.

[16] J. Carter, "General Introduction" in Understanding Religious Sacrifice: A Reader, ed. by J. Carter, London: Continuum, 2003, pp. 2-7.

[17] P. Cartledge, "Deep plays': theatre as process in Greek civic life in The Cambridge Companion to Greek Tragedy, ed. by P. E. Easterling, Cambridge: Cambridge University Press, 1997, pp. 5-11.

[18] J. R. Green, Theatre in Ancient Greek Society, London: Routledge, 1994, pp. 62-64.

[19] L. Orrey, Opera: a concise history, ed. by R. Milnes, London: Thames \& Hudson, 1987, pp. 9-18.

[20] P. J. Smith, “'O Patria Mia': Female Homosociality and the Gendered Nation in Bellini's Norma and Verdi's Aida" in The Work of Opera: Genre, Nationhood, and Sexual Difference, ed. by R. Dellamora and D. Fischlin, New York: Columbia University Press, 1997, pp. 94-95.

[21] J. Bokina, Opera and Politic: From Monteverdi to Henze, London: Yale University Press, 1997, pp. 2.

[22] R. Girard, Violence and the Sacred, Baltimore: The John Hopkins University Press, 1977, pp. 6.

[23] H. Hubert and M. Mauss, Sacrifice: Its Nature and Functions, trans. by W. D. Halls, p. 71-72.

[24] W. H. Auden, Secondary World, London: Faber \& Faber, 1968, pp. 41-45.

[25] J. Rosselli, Singers of Italian Opera: The History of a Profession, Cambridge: Cambridge University Press, 1992, pp. 114.

[26] W. H. Auden, Secondary Worlds, p. 13-14.

[27] L. Kramer, After the Lovedeath: Sexual Violence and the Making of Culture, London: University of California Press, 1997, pp. 1-4. 
[28] W. H. Auden, Forewords and Afterwords, London: Faber and Faber, 1973, pp. 345-350.

[29] W. H. Auden, Forewords and Afterwords, London: Faber and Faber, 1973, pp. 349.

[30] D. J. Grout and H. W. Williams, A Short History of Opera, p. 3.

[31] A. E. Jensen, Myth and Cult: Among Primitive People, trans. by M. T. Choldin and W. Weissleder, pp. 59-64.

[32] E. W. White, "Court Masque" in A History of English Opera, London: Faber and Faber, 1983, pp. 40-48.

[33] A. Groos, "Introduction" in Reading Opera, ed. by A. Groos and R. Parker, Princeton: Princeton University Press, 1988, pp. 10.

\section{Biography}

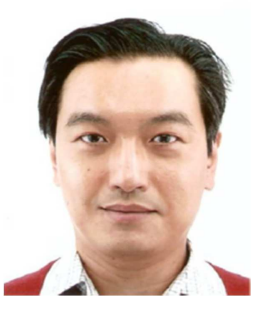

Alexander Chih-Yuan Mai received his $\mathrm{PhD}$ at the University of Glasgow, UK in the field of English Literature. His $\mathrm{PhD}$ thesis is focused on English operatic libretti for the second half of the twentieth-century. After the completion of his doctorate degree, Alexander went on to study classical singing in London and then worked as an opera singer until 2017. In April 2019 Alexander relocated to Osaka, Japan where he works as an assistance professor at Kansai Gaidai University. 